\title{
Biozote-P Application under Zero Tillage Drill Wheat Planting Influenced Yield and Phosphorus use Efficiency of Wheat Crop
}

\author{
Ghulam Muhammad ${ }^{1}$, Shahinshah Khan ${ }^{2}$, Mustajab A. Khan ${ }^{2}$, Javed Anjum ${ }^{1}$, Nazeer Ahmed Alizai ${ }^{1}$, Kamran \\ Anjum $^{1}$, Abdul Ghafoor ${ }^{1}$, Hidayatullah Kakar ${ }^{*}$ \\ ${ }^{1}$ Agriculture Research Institute, Quetta, Balochistan, Pakistan \\ ${ }^{2}$ Balochistan Agriculture College Quetta, Pakistan \\ *Correspondence: kaintkk@gmail.com
}

Article Received 14-10-2021, Article Revised 28-12-2021, Article Accepted 20-01-2022

\begin{abstract}
The availability of phosphorus is limited in calcareous soil because of the chemical reaction between calcium and phosphorus by converting it into calcium phosphate. The application of phosphorus solubilizing bacteria as biofertilizer might help in the availability of phosphorus in soil. So, this study was aimed to enhance phosphorus use efficiency (PUE), growth, and yield of wheat planted by zero tillage drill after rice harvest using biozote-P as a microbial inoculant. Three treatments $\left(\mathrm{T}_{1}=\right.$ Traditional wheat planting (control), $\mathrm{T}_{2}=$ Zero-tillage Drill wheat planting, and $\mathrm{T}_{3}=$ Zero-tillage Drill wheat planting + Biozote-P) were tested in the rice harvested field at Usta Muhammad, Balochistan during 2019-20. Each treatment was comprised of one acre and the collected data were subjected to descriptive statistics included minimum, maximum, mean, standard deviation, and standard error. The pre soil properties revealed that the soil was clayey, alkaline $(\mathrm{pH}>8.0)$ with low soil organic matter, total nitrogen, and available phosphorus contents. However, post soil properties showed increase in soil organic matter with marginal level reduction in soil $\mathrm{pH}$ along with improvement in the availability of total nitrogen $(0.051 \%)$ and phosphorus (4.31 mg kg-1) in T3. The ZT and ZT+Biozote-P increased grain yield by 32.09 and $36.94 \%$ over traditional wheat planting. So, phosphorus use efficiency (PUE) was increased by 41.77 and $29.22 \%$ in $\mathrm{T}_{3}$. It means that Biozote-P application under zero tillage drill improved PUE by $9.71 \%$ in comparison to sole zero tillage drill wheat planting. Subsequently, it is inferred that biozote-P (microbial inoculant) can be included in ZT wheat planting in rice-wheat cropping zone of Balochistan.
\end{abstract}

Keywords: Biozote-P, microbial inoculant, nutrient use efficiency, wheat, yield

\section{Introduction}

Recent research work in rice-wheat cropping system is mainly focused on management practices for monitoring the fluctuations in crop establishment techniques (CETs) (Decker et al., 2009; Gangwar et al., 2009; Singh et al., 2018). Crop establishment techniques varied across usage of resources (Bhushan et al., 2007), demand of energy (Frenstein et al., 2008; Eskandari and Attar 2015) and climate change mitigation's capacity (Li et al., 2013) that lead to far reaching influence on crop yield and livelihood of growers along with consequences of healthy environment (Frenstein and Laxmi, 2008; Gopalakrishnan, 2014). In addition to that the best management practices (BMP) and latest crop establishment technique are now significantly adopted on large scale as a solution of natural resources conservation and an alternative of the present escalating prices of synthetic fertilizers and other costly production intervention. Late planting of wheat was identified as a major cause of reduced yields. In Pakistan, about $80 \%$ of the wheat is planted late (Gill et al., 2013; Shahane et al.,2020). Because of the shorter growing period coupled with delayed planting, wheat grain filling stage coincides with high temperature leading to a large yield penalty. However, timely sowing provides enough time to crop growth and thus enhanced yield (Jat et al., 2014). In Pakistan, wheat crop is almost planted before the end of November and further each day beyond this time has led to decrease in yield by $1-1.5 \%$ through each day delay. In rice-wheat cropping system, the majority of farmers carried out wheat sowing late because of manifold operations involved after the harvesting of rice because they think that such tillage operations are prerequisite for better germination and crop stand (Chauhan et al., 2000). After rice harvest, the soil moisture is high and the farmers wait for optimum moisture attainment, then plough the field for mixing the rice stubbles and then again irrigate the field for proper eradication of rice stubbles. When the field reaches to field capacity moisture level, then ploughed 3-4 times to get field properly prepared for wheat sowing such tillage operations lead to late sowing and results in low yield. To address the timely wheat sowing after rice harvest, Zero-Tillage technology has been introduced all the over the world which sow the seed directly in rice stubbles without disturbing the field. Zero-Tillage drill is a resource conservation technology that helped in fuel saving (i.e. required 36 $\mathrm{L}$ less diesel $\mathrm{ha}^{-1}$ ), reduced labor cost and low farm operation $(15-16 \%)$ that led to increase in farm income by 100 US dollar ha-1 and increased wheat yield by 5$7 \%$ (Erenstein, 2009). The main benefits of zero-tillage drill wheat planting are reduction in land degradation, augmented soil organic carbon, improved soil structure and saved first irrigation by sowing wheat on the residual moisture of rice that helped in reducing irrigation requirement (i.e. saved 1.0 million letters ha$\left.{ }^{1}\right)$. According to some estimates that additional 2.0 million tons of wheat in Pakistan can be obtained if wheat is planted two weeks earlier (Gill et al., 2013). 
The soil biodiversity plays significant role in soil health and fertility. Soil microorganism are the major component of biodiversity and it helps in global nutrient cycling and decomposition of organic matter (Vessey, 2003). It plays a significant role in soil fertility in term of atmospheric nitrogen fixation, sulfur and phosphorus solubilization and assist in releasing of plant growth hormones in soil system leading to increase yield of crops by $10-15 \%$ (Mostara et al., 1995; Venkatashwarlu, 2008). Different research Institutions in Pakistan are indulged in production of biofertilizers and sold commercially. Among them, PARC (Pakistan Agriculture Research Council) Islamabad is manufacturing biofertilizer viz. Biozote (i.e. living bacteria TAL-169) formulated in a carrier material. Biozote have been tested on legume and cereal crops and have observed $20-40 \%$ increase in yield (Hussain et al., 1981; khan et al., 2017). Another group of researchers noted similar results that used biofertilizer in wheat when planted by zero-tillage drill after rice harvest and observed greater biological yield $\left(22.23 \mathrm{t} \mathrm{ha}^{-1}\right)$ of wheat where $75 \%$ recommended $\mathrm{N}$ was applied. In addition to that higher NPK uptake of $284.5,29.6$ and $255.7 \mathrm{~kg} \mathrm{ha}^{-1}$ by wheat crop was noted when planted by zero-tillage drill and receiving $75 \%$ recommended nutrients + microbial inoculum+zinc (Shahane et al., 2020). Rice wheat cropping system is practiced in Jaffarabad and Nasirabad districts of Balochistan which is the only agricultural area where canal irrigation system is available. After rice harvest, wheat crop is cultivated late due to the presence of residual moisture of rice crop. Before the introduction of Zero Tillage Drill, wheat crop was grown on traditional method where soil was ploughed two or three times and stubbles of rice were destroyed by direct field burning and subsequent mixing in the soil. Most of time the clods were demolished through rotavator and in this way wheat crop was established by high production cost with late sowing that resulted in low yield and low efficiency of applied fertilizer. During 2014, ICARDA (International Center for Agriculture Research in Dry Areas) introduced Zero Tillage Drill in the area. Now, there are more than 400 Zero Tillage Drills in Usta Muhammad and majority of the farmers are planting wheat by $\mathrm{ZT}$ drill after rice harvest where wheat crop is grown in time with low production cost. Keeping in view the importance of zero tillage, this investigation was undertaken to improve phosphorus use efficiency and wheat performance planted by Zero Tillage Drill after rice harvest through integration of biozot-P.

\section{Materials and Methods}

The inoculum of phosphorus solubilizing bacteria (Biozote-P) was studied in field experiment on wheat crop planted by zero tillage drill after rice harvest and compared it with conventional planting and zero tillage wheat planning without biozote-P. Biozote-P was purchased from PATCO NARC, Islamabad and wheat seeds were inoculated following its application procedure and then dried in the shed. Three acre land was selected in rice harvest area at Usta Muhammad during 2019, and wheat crop was planted as per treatments included $\mathrm{T}_{1}=$ Traditional wheat planting (control), $\mathrm{T}_{2}=$ Zero-tillage Drill wheat planting and $\mathrm{T}_{3}$ $=$ Zero-tillage drill wheat planting + Biozote-P. When moisture contents reached to field capacity after rice harvest, wheat variety Umeed-2014 was planted using seed rate of $50 \mathrm{~kg} \mathrm{acre}^{-1}$. The recommended nutrients i.e. 120-90-60 kg NPK $\mathrm{ha}^{-1}$ were applied using nitrophos, urea and SOP fertilizers. Both nitrophos and SOP were applied through zero tillage drill at the time of planting while urea was applied in two equal splits at the time of $1^{\text {st }}$ and $2^{\text {nd }}$ irrigation. During crop growth and at maturity, ten plants were selected randomly in each treatment for recording plant height $(\mathrm{cm})$, leaf area $\left(\mathrm{cm}^{2}\right.$ plant $\left.^{-1}\right)$, leaf area index, spike length, and number of spikelet spike ${ }^{-1}$. While, $1 \mathrm{~m}^{2}$ area was selected using square iron band from 3 places randomly and harvested for determination of number of tillers $\mathrm{m}^{-2}$, seed index, harvest index, biological yield $\left(\mathrm{t} \mathrm{ha}^{-1}\right)$, and grain yield $\left(\mathrm{t} \mathrm{ha}^{-1}\right)$. Further, leaf and grain tissue nutrient concentration, nutrient uptake (NPK kg ha-1) and phosphorus use efficiency of wheat crop was found.

Plant height in centimeter was measured from the surface of the ground to the tip of flag leaf with the help of measuring tape; at the time of harvest tillers $\mathrm{m}^{-2}$ were counted per treatment; spike length was noted with measuring tape; for spikelet spike $^{-1}, 25$ spikes per treatment were selected randomly and counted spikelet spike $^{-1}$ and converted into average; sun-dried seeds of each treatment were taken and weighed 1000 seed as seed index; both biological and grain yield of $\mathrm{m}^{-2}$ were obtained at the time of harvest and converted it into $\mathrm{tha}^{-1}$ and harvest index was calculated as a ratio of grain and biological yield.

Nutrient uptake $\left(\mathrm{kg} \mathrm{ha}^{-1}\right)$ :

N-uptake: Nitrogen uptake was calculated through TDM $\mathrm{x} N$ concentration in plant/(100).

P-uptake: Phosphorus uptake was observed through TDM x P concentration in plant /(100).

K-uptake: Potassium uptake was observed through TDM $\mathrm{x}$ K concentration in plant /(100).

Soil analysis: The experimental site was sampled before crop sowing and after harvest for determination of soil physicochemical properties. The collected soil samples were delivered to Directorate of Agriculture Research Soil and Water Testing, ARI-Sariab Quetta where sampling processes were carried out and analyzed for Texture, EC (electrical conductivity), $\mathrm{pH}$, SOM (soil organic matter), TN (total nitrogen), and available $\mathrm{P}$ (phosphorus) and $\mathrm{K}$ (potassium). Hydrometer method was used for textural analysis (Bouyoucos, 1962). Soil textural class was determined by plotting the percentage of sand, silt and clay on texture triangle proposed by USDA. Soil and water suspension of 2:1 was prepared for determination of EC and pH using the method described by McKeague (1978) and McLean (1983). While, oxidation method 
was used for detecting soil organic matter contents (Walkley, 1947; Black, 1973). The total nitrogen content of soil was found by Kjeldahl method (Bremner, 1965). For the determination of available phosphorus and potassium in soil, Ammonium bicarbonate-diethylene triamine pentaacetic acid (ABDTPA) method was used (Soltanpour and Schwab, 1977). In this method, soil was extracted by AB-DTPA solution in the ratio of 1:2. In the clear filtrate, $\mathrm{P}$ was determined by absorption spectrophotometry ((Shimadzu UV-180) using molybdenumblue coloring agent. Before taking reading of samples, working standards with range of $0,2,4,6$ and $\mathrm{mg} \mathrm{L}^{-1}$ were run on wavelength of $880 \mathrm{~nm}$ and then the samples containing coloring agent were run i.e developed color intensity after 15 minutes. The concentration of $\mathrm{P}$ in the samples were calculated from linear graph of standards. While, $\mathrm{K}$ in the clear extract was determined by absorption spectroscopy using Flame photometer (Jenway PFP-7). The flame photometer was first standardized by running series of $\mathrm{K}$ working standards solution containing $\mathrm{K}$ level as 5, 10, 20, 30, 40, 50,60, 80,90 and $100 \mathrm{mg} \mathrm{L}^{-1}$. The absorbance of samples was recorded on flame photometer and their $\mathrm{K}$ concentration was calculated from linear graph as developed between absorbance of $\mathrm{K}$ standards solutions and their respective concentrations.

Plant test methods: Leaf and grain tissue of wheat were digested in sulfuric acid $\left(\mathrm{H}_{2} \mathrm{SO}_{4}\right)$ with intermittent addition of hydrogen peroxide $\left(\mathrm{H}_{2} \mathrm{O}_{2}\right)$. In this wet digestion method, $0.5 \mathrm{~g}$ plant tissue were taken in Kjeldahl flask added $5.0 \mathrm{ml} \mathrm{H}_{2} \mathrm{SO}_{4}$ and digested on low temperature for 1 hour. After cooling $2.0 \mathrm{ml} \mathrm{H}_{2} \mathrm{O}_{2}$ was added and heated on high temperature for 10 minutes. Repeated addition of $2.0 \mathrm{ml} \mathrm{H} \mathrm{H}_{2} \mathrm{O}_{2}$ until the clear digest was obtained (Wolf, 1982). Total nitrogen, phosphorus and potassium in the clear digest of both tissues were determined following the standard procedure. Total $\mathrm{N}$ was determined by Kjeldahl method (Bremner, 1965). While P concentration in the clear digest was determined on spectrophotometer at $480 \mathrm{~nm}$ after running series of working standards and the digested samples. Color of vanadomolybdophosphoric acid were developed in both plant tissue digested samples and the $\mathrm{P}$ working standards following the method described by Cottenie (1980). The concentration of $\mathrm{P}$ in the samples were calculated from linear graph of working standards. Whereas, $\mathrm{K}$ concentration was directly measured on flame photometer as described by Knudsen (1982) in the same as soil $\mathrm{K}$ was detected i.e. firstly run the set of $\mathrm{K}$ working standards and then the digested samples. The linear graph developed for working standards was used for calculation of $\mathrm{K}$ concentration in the samples.

Statistical analysis:The data were tabulated using minimum, maximum, mean and standard deviation obtained through descriptive statistics.

\section{Result and discussion}

In rice wheat cropping system, wheat crop is sown late which is one main of the constraints leading to yield stagnation. The introduction of zero-tillage intervention proved as an integrated approach towards timely planting of wheat that further helped in eradication of weeds and augmentation of fertilizer and water use efficiency (Malik and Singh, 1995; Malik, 1996; Hobbs et al., 1997, 2002). Similar benefits of zero-tillage wheat planting were reported by Hobbs et al. (1997) who noted reduction in weed infestation of Phalaris minor due to timely sowing of wheat after rice harvest. Number of acreages of wheat planting by zero tillage drill has increased significantly as 30,000 acres reported during 2000-01 that further enhanced by 80,000 acres during 2001-02. This high adoption of wheat planting by zero tillage drill is mainly attributed to timely sowing with low cost along with augmentation of water and fertilizer use efficiency that overall led to increase in yield.

Pre and post soil properties: The availability of phosphorus is limited in calcareous soil due to formation of calcium phosphate that ultimately reduces the efficiency of applied phosphatic fertilizer. The application of phosphorus solubilizing bacteria as biofertilizer will help in the availability of buildup phosphorus in soil as well as the applied phosphatic fertilizer. To further enhance the efficiency of ZT drill wheat planting, Biozote-P inoculant was applied to wheat seed before planting and then planted by ZT drill after rice harvest. This study was focused on phosphorus use efficiency and growth performance of wheat under traditional and ZT drill wheat planting with and without Biozote-P application. The results pertaining to pre and post soil properties of the experimental site is given in Table 1 . Texturally, the soil was clayey and alkaline $(\mathrm{pH}>8.0)$ with marginal and single digit shift in post soil $\mathrm{pH}$ i.e. from 8.21 to 8.18 was observed under ZT drill and ZT drill+Biozote-P. Soil organic matter status revealed that before cultivation of wheat SOM was noted in low ranges but after completion of production cycle of wheat SOM was found in marginal to adequate ranges and maximum SOM of $0.92 \%$ was recorded in plot where wheat seeds were inoculated with Biozote-P and then planted by ZT Drill followed by $0.87 \%$ in ZT drill planted wheat plot without Biozote-P. This demonstrates that ZT drill wheat planting after rice harvest help in buildup of SOM due to slow and steady decomposition of rice stubble during wheat production. Such enhancement in SOM might have resulted in marginal shift in soil $\mathrm{pH}$. In case of total nitrogen (TN) and AB-DTPA extractable $\mathrm{P}$ and $\mathrm{K}$ contents of pre and post soil analysis revealed that both $\mathrm{TN}$ and $\mathrm{P}$ were low but AB-DTPA extractable $\mathrm{K}$ was noted in higher range in pre soil. While, post soil properties revealed augmentation in TN and AB-DPTA extractable P with higher TN $(0.051 \%)$ and AB-DTPA extractable P (4.31 $\left.\mathrm{mg} \mathrm{kg}{ }^{-1}\right)$ in plot where wheat seeds were inoculated with Biozote-P and then planted by Zero Tillage Drill (Table 1). Whereas, $\mathrm{K}$ status in post soil remain in 
higher ranges with marginal changes in plot where wheat was planted by ZT Drill and ZT. Drill +Biozote$\mathrm{P}$. The improvement in post soil TN and available $\mathrm{P}$ was due to enhancement in soil organic matter. Such improvement in soil properties was also recorded by Venkatashwarlu (2008) who used phosphorus solubilizing bacteria in wheat crop at the time of sowing. Biofertilizer perform many functions when used as seed inoculants for various crops because it works for biological nitrogen fixation and enhance solubility of soil fixed and applied phosphorus and release some important substances in soil vital for improving plant growth

Table 1. Pre and post soil properties of the experimental site

\begin{tabular}{|l|l|c|c|c|c|c|c|}
\hline \multirow{2}{*}{ Soil properties } & \multirow{2}{*}{ Unit } & \multicolumn{3}{c|}{ Pre soil properties } & \multicolumn{3}{c|}{ Post soil properties } \\
\cline { 3 - 8 } & & Trad. & $\begin{array}{c}\text { ZT. } \\
\text { Drill }\end{array}$ & $\begin{array}{c}\text { ZT. Drill } \\
+ \text { +Biozote-P }\end{array}$ & Trad. & ZT. Drill & $\begin{array}{c}\text { ZT. Drill } \\
+ \text { Biozote-P }\end{array}$ \\
\hline Soil texture & & Clayey & Clayey & Clayey & Clayey & Clayey & Clayey \\
\hline Organic matter & $\%$ & 0.61 & 0.65 & 0.60 & 0.75 & 0.87 & 0.92 \\
\hline $\mathrm{pH}$ & & 8.21 & 8.21 & 8.21 & 8.20 & 8.18 & 8.18 \\
\hline $\mathrm{EC}_{1: 2}$ & $\mathrm{dSm}^{-1}$ & 2.4 & 2.43 & 2.22 & 2.4 & 2.44 & 2.28 \\
\hline $\mathrm{CaCO}_{3}$ & $\%$ & 19.4 & 19.6 & 19.2 & 19.5 & 19.7 & 19.7 \\
\hline Total nitrogen & $\%$ & 0.036 & 0.037 & 0.035 & 0.043 & 0.049 & 0.051 \\
\hline $\begin{array}{l}\text { AB-DTPA } \\
\text { extractable P }\end{array}$ & $\mathrm{mg} \mathrm{kg}{ }^{-1}$ & 2.18 & 2.13 & 2.15 & 2.22 & 3.12 & 4.31 \\
\hline $\begin{array}{l}\text { AB-DTPA } \\
\text { extractable K }\end{array}$ & $\mathrm{mg} \mathrm{kg}^{-1}$ & 114.5 & 114.8 & 115.1 & 117.2 & 121.6 & 122.4 \\
\hline
\end{tabular}

Growth performance of wheat: Performance of wheat crop as planted by Zero Tillage Drill after rice harvest was affected under the influenced of Biozote-P application (Table 2). Among the planting techniques, inoculated seed of wheat with Biozote-P planted by Zero Tillage Drill after rice produced greater mean plant height $(89.4 \pm 1.43 \mathrm{~cm})$, leaf area $(308.2 \pm 8.08$ $\mathrm{cm}^{2}$ plant $\left.{ }^{-1}\right)$, leaf index $(1.04 \pm 0.10)$, number of tillers $\left(386.2 \pm 10.43 \mathrm{~m}^{-2}\right)$, spike length $(10.18 \pm 0.40 \mathrm{~cm})$, spikelet spike $^{-1}(18.2 \pm 0.84)$, seed index $(41.16 \pm 1.86$ $\mathrm{g})$, biological yield $\left(9.01 \pm 0.69 \mathrm{t} \mathrm{ha}^{-1}\right)$ and grain yield $\left(3.67 \pm 0.20 \mathrm{t} \mathrm{ha}^{-1}\right)$ respectively. However, traditional method of wheat planting after rice harvest have resulted in reduction of all the growth parameters under study over Zero Tillage Drill wheat planting with and without Biozote-P application as seed treatment. The comparison in yield across two planting techniques i.e. traditional and Zero Tillage Drill revealed that $\mathrm{ZT}$ and $\mathrm{ZT}+$ Biozote-P increased grain yield by 32.09 and $36.94 \%$ over traditional wheat planting after rice harvest. The seed treatment with Biozote-P and then planting by Zero Tillage Drill increased yield by $3.67 \%$ as compared to Zero Tillage Drill wheat planting without Biozote-P. This demonstrates that Zero Tillage Drill ensured not only timely wheat planting after rice harvest but also increased soil organic matter level leading to improved soil physical, chemical and biological properties. Such improvement in soil properties helped in boosting overall growth of wheat crop with better crop stand and enhancement of yield contributing factors that resulted in higher biological and grain yield (Table 2). These results are in line with the findings reported by various researchers who observed that the crop stand is improved for wheat sown with zero-tillage drill and a 10 to 40 percent higher yield can be realized under different soil types and wheat sowing regimes as compared to that obtained under conventional systems (Aslam et al. 1989; Khan et al., 2017). The efficiency of Zero Tillage Drill wheat planting was further increased when wheat seed was inoculated with Biozote-P, a phosphorus solubilizing bacteria inoculum. Several studies have shown that augmentation in growth parameters under the influence of biofertilizer might be due the ability of microorganisms to solubilize nutrients and also due to the release of growth stimulating hormones (Stamenković et al., 2018).

Leaf and grain tissue nutrient concentration: The primary nutrients such as $\mathrm{N}, \mathrm{P}$ and $\mathrm{K}$ accumulation in leaf and grain tissue of wheat was affected by traditional and Zero Tillage Drill wheat planting after rice harvest as shown in Table 2 . Generally, leaf tissue $\mathrm{N}$ was ranged from 1.8 to $2.7 \%$ with mean value of $2.22 \pm 0.43 \%, \mathrm{P}$ from 0.38 to $0.46 \%$ with mean value of $0.43 \pm 0.03 \%$ and $\mathrm{K}$ was ranged from 1.77 to $2.11 \%$ with mean value of $1.95 \pm 0.15 \%$ when wheat was planted by traditional method; Zero Tillage Drill wheat planting expressed leaf tissue $\mathrm{N}$ in the range of 2.8$3.1 \%$ with mean value of $2.92 \pm 0.11$, P from 0.47 $0.64 \%$ with mean of $0.53 \pm 0.07 \%$ and $\mathrm{K}$ was ranged from 2.10 to $2.88 \%$ with mean of $2.51 \pm 0.35 \%$; wheat seed inoculated with Biozote-P and planted by Zero Tillage Drill showed leaf tissue $\mathrm{N}$ in the range of 2.8 to $3.2 \%$ with mean value of $3.0 \pm 0.16 \%$, $\mathrm{P}$ from 0.67 to $0.87 \%$ with mean value of $0.76 \pm 0.07 \%$ and $\mathrm{K}$ from 2.97 to $2.31 \%$ with mean value of $2.58 \pm 0.25 \%$ respectively. The results manifested that wheat growth was comparatively improved under Zero Tillage Drill+Biozote-P which is evidenced from higher leaf tissue $\mathrm{N}, \mathrm{P}$ and $\mathrm{K}$ concentration. As compared to traditional wheat planting after rice harvest, Zero Tillage Drill wheat planting ensured better crop stand establishment and maximum nutrient accumulation 
both with and without Biozote-P application. Our results are in line with findings of a group of researchers who conducted field experiment and studied the performance of wheat crop when seeds of wheat were inoculated with phosphorus solubilizing bacteria as biofertilizer (Dal Cortivo et al., 2020) and recorded greater leaf tissue $\mathrm{N}$ accumulation and improvement in wheat growth. They advocated that seed inoculation with biofertilizer might be substantially used in wheat cultivation on sustainable basis.

Grain tissue primary nutrient concentration was increased when wheat was planted by Zero Tillage Drill over traditional wheat planting (Table 2). The higher mean $\mathrm{N}, \mathrm{P}$ and $\mathrm{K}$ concentration $(0.95 \pm 0.05$, $0.70 \pm 0.03$ and $0.88 \pm 0.09 \%$ ) were observed in plot where wheat seeds were treated with Biozote-P and planted by ZT Drill. While lower grain tissue mean $\mathrm{N}$, $\mathrm{P}$ and $\mathrm{K}(0.68 \pm 0.08,0.49 \pm 0.08$ and $0.79 \pm 0.09 \%)$ were recorded in plot where wheat was planted by traditional method after rice harvest. This demonstrates that Zero Tillage Drill wheat planting with and without Biozote-P application increased grain $\mathrm{N}$ by 39.71 and $26.47 \%$, P by 42.86 and $18.37 \%$ while K by $11.39 \%$ respectively over traditional wheat planting. These results are in accordance with the findings of $\mathrm{Dal}$ Cortivo et al. (2020) who also observed higher grain tissue nutrient concentration under Zero Tillage Drill wheat planting as compared to traditional wheat planting after rice harvest. According to Khan et al. (2017) that grain yield of both leguminous and cereal crops increased by 20 to $40 \%$ by the use of Biozote, a biofertilizer developed by Pakistan Agriculture Research Council in various formulation containing multiple microorganisms responsible for biological nitrogen fixation, phosphorus solubilizing and release of different plant growth promoting hormones like indole acetic acid and gibberellic acid.

Nutrient uptake and phosphorus use efficiency: The availability of nutrients to crop is one of the main constraints in agriculture productivity under alkaline and calcareous heavy soil. In rice-wheat cropping region of Balochistan, after rice harvest wheat cultivation get late leading to low yield and low nutrient uptake. Wheat nutrients uptake $\left(\mathrm{kg} \mathrm{ha}^{-1}\right)$ were influenced by planting after rice harvest with and without Biozote-P (Figure 1a,b\&c). Under traditional wheat planting, $\mathrm{N}$ uptake was ranged from 90.85 to $181.2 \mathrm{~kg} \mathrm{ha}^{-1}$ with mean value of $131.42 \mathrm{~kg} \mathrm{ha}^{-1}, \mathrm{P}$ from 30.07 to $45.12 \mathrm{~kg} \mathrm{ha}^{-1}$ with mean of $35.28 \mathrm{~kg} \mathrm{ha}^{-}$ ${ }^{1}$, and $\mathrm{K}$ uptake was ranged from 99.47 to $155.55 \mathrm{~kg}$ $\mathrm{ha}^{-1}$ with mean value of $119.98 \mathrm{~kg} \mathrm{ha}^{-1}$. wheat crop sown by Zero Tillage Drill revealed $\mathrm{N}$ uptake in the range of 156.8 to $200.46 \mathrm{~kg} \mathrm{ha}^{-1}$ with mean value of $174.1 \mathrm{~kg} \mathrm{ha}^{-1}$, P uptake from 42.6 to $52.62 \mathrm{~kg} \mathrm{ha}^{-1}$ with mean value of $46.62 \mathrm{~kg} \mathrm{ha}^{-1}$ and $\mathrm{K}$ from 124.14 to $183.88 \mathrm{~kg} \mathrm{ha}^{-1}$ with mean of $155.04 \mathrm{~kg} \mathrm{ha}^{-1}$ respectively. Similarly, Zero Tillage Drill wheat planting with application of Biozote-P expressed $\mathrm{N}$ uptake in the range of 164.8 to $215.2 \mathrm{~kg} \mathrm{ha}^{-1}$ with mean value of $194.7 \mathrm{~kg} \mathrm{ha}^{-1}$, P from 58.37 to $69.52 \mathrm{~kg} \mathrm{ha}^{-1}$ with mean value of $66.52 \mathrm{~kg} \mathrm{ha}^{-1}$ and $\mathrm{K}$ uptake from 135.35 to $185.16 \mathrm{~kg} \mathrm{ha}^{-1}$ with mean value of $170.07 \mathrm{~kg}$ $\mathrm{ha}^{-1}$ respectively. This demonstrate that wheat planting by Zero Tillage Drill after rice harvest improved $\mathrm{P}$ uptake by $24.34 \%$ over traditional wheat planting after rice harvest while, use of Biozote-P for wheat seed inoculation and planting by Zero Tillage Drill improved P uptake by $67.91 \%$ over traditional planting (Figure 1b). According to Chauhan et al. (2015) that nitrogen use efficiency can be enhanced in many crop using biofertilizers. Some free living nitrogen fixers like Azotobacter and Azospirillum when used as biofertilizers can stimulate initiation of root hairs along with development of lateral as well as adventitious roots by changing the plant hormones like auxins (Vejan et al., 2016; Zeffa et al., 2019). So, phosphorus use efficiency (PUE) was increased by 41.77 and $29.22 \%$ when wheat was planted by Zero Tillage Drill with and without usage of Biozote-P as compared to traditional (Figure 1d). It means that Biozote-P application under Zero Tillage Drill improved PUE by $9.71 \%$ in comparison to sole Zero tillage drill wheat planting without Biozote-P application. Such improvement in PUE might be due to acidification of rhizosphere by Biozote-P that helped in solubilization of fixed and applied phosphorus as reported by Afzal and Bano (2008) and Meena et al. (2014). According to some other group of researchers that the inoculum of Bacillus megaterium and Frateuria aurantia have a potential to solubilize phosphorus and potassium when applied as seed inoculants that can be used for various crops (Subhashini, 2014; Ghaffari et al., 2018).

\section{Conclusion}

In rice wheat cropping system, wheat planting by zero tillage drill after rice harvest have resulted in higher growth traits and yield and increased nutrient use efficiency as compared to conventional wheat planting after rice harvest. The performance of zero tillage wheat planting augmented manifold when microbial inoculum was also used which resulted increased in yield by $36.94 \%$ over traditional and $3.67 \%$ over zero tillage drill wheat planting without Biozote-P. So, phosphorus use efficiency (PUE) was increased by 41.77 and $29.22 \%$ when wheat was planted by zero tillage Drill with and without usage of Biozote-P as compared to traditional. It means that Biozote-P application under Zero Tillage Drill improved PUE by $9.71 \%$ in comparison to sole zero tillage drillwheat planting without Biozote-P application. Consequently, it is suggested that biozote$\mathrm{P}$ like microbial inoculant can be included in wheat planting in rice-wheat cropping zone of Balochistan 
Table 2. Performance of wheat crop under the influence of Biozote-P application when planted by Zero Tillage Drill after rice harvest

\begin{tabular}{|c|c|c|c|c|c|c|c|c|c|}
\hline \multirow[t]{3}{*}{ Parameters } & \multicolumn{9}{|c|}{ Wheat planting method after rice harvest } \\
\hline & \multicolumn{3}{|c|}{ Traditional } & \multicolumn{3}{|c|}{ Zero Tillage Drill } & \multicolumn{3}{|c|}{ Zero Tillage Drill + Biozote-P } \\
\hline & ${ }^{\#}$ Min & Max & Mean \pm S.D & Min & Max & Mean \pm S.D & Min & Max & Mean \pm S.D \\
\hline Plant height $(\mathrm{cm})$ & 68.9 & 87.5 & $79.06 \pm 7.09$ & 85.1 & 90.2 & $87.8 \pm 2.07$ & 87.6 & 91.3 & $89.4 \pm 1.43$ \\
\hline Leaf area $\left(\mathrm{cm}^{2}\right)$ plant $^{-1}$ & 228.2 & 237.2 & $231.9 \pm 3.63$ & 269.3 & 290.2 & $279.5 \pm 7.53$ & 298.4 & 317.4 & $308.2 \pm 8.08$ \\
\hline Leaf area index & 0.68 & 0.79 & $0.74 \pm 0.05$ & 0.85 & 0.98 & $0.92 \pm 0.05$ & 0.96 & 1.2 & $1.04 \pm 0.10$ \\
\hline No. of tillers $\mathrm{m}^{-2}$ & 298 & 334 & $320.6 \pm 13.89$ & 376 & 395 & $384.4 \pm 7.96$ & 368 & 393 & $386.2 \pm 10.43$ \\
\hline Spike length $(\mathrm{cm})$ & 7.4 & 9.1 & $8.32 \pm 0.72$ & 8.9 & 10.6 & $9.88 \pm 0.64$ & 9.7 & 10.5 & $10.18 \pm 0.40$ \\
\hline Spikelet spike ${ }^{-1}$ & 14 & 16 & $15.2 \pm 0.84$ & 16 & 19 & $17.2 \pm 1.30$ & 17 & 19 & $18.2 \pm 0.84$ \\
\hline Seed index & 35.6 & 40.2 & $38.26 \pm 1.88$ & 38.7 & 42.1 & $40.52 \pm 1.29$ & 38.7 & 43.2 & $41.16 \pm 1.86$ \\
\hline Harvest index & 0.32 & 0.37 & $0.35 \pm 0.02$ & 0.39 & 0.46 & $0.42 \pm 0.03$ & 0.36 & 0.45 & $0.41 \pm 0.04$ \\
\hline Biological yield $\left(\mathrm{t} \mathrm{ha}^{-1}\right)$ & 6.7 & 9.2 & $7.76 \pm 1.09$ & 7.9 & 9.2 & $8.46 \pm 0.53$ & 8.10 & 10.0 & $9.01 \pm 0.69$ \\
\hline Grain yield $\left(\mathrm{t} \mathrm{ha}^{-1}\right)$ & 2.5 & 2.9 & $2.68 \pm 0.20$ & 3.2 & 3.8 & $3.54 \pm 0.22$ & 3.5 & 3.95 & $3.67 \pm 0.20$ \\
\hline \multicolumn{10}{|c|}{ Leaf tissue nutrient contents (\%) } \\
\hline $\mathrm{N}$ & 1.8 & 2.7 & $2.22 \pm 0.43$ & 2.8 & 3.1 & $2.92 \pm 0.11$ & 2.8 & 3.2 & $3.0 \pm 0.16$ \\
\hline $\mathrm{P}$ & 0.38 & 0.46 & $0.43 \pm 0.03$ & 0.47 & 0.64 & $0.53 \pm 0.07$ & 0.67 & 0.87 & $0.76 \pm 0.07$ \\
\hline $\mathrm{K}$ & 1.77 & 2.11 & $1.95 \pm 0.15$ & 2.10 & 2.88 & $2.51 \pm 0.35$ & 2.97 & 2.31 & $2.58 \pm 0.25$ \\
\hline \multicolumn{10}{|c|}{ Grain tissue nutrient contents (\%) } \\
\hline $\mathrm{N}$ & 0.60 & 0.78 & $0.68 \pm 0.08$ & 0.82 & 0.89 & $0.86 \pm 0.03$ & 0.87 & 1.00 & $0.95 \pm 0.05$ \\
\hline $\mathrm{P}$ & 0.43 & 0.60 & $0.49 \pm 0.08$ & 0.51 & 0.66 & $0.58 \pm 0.06$ & 0.65 & 0.74 & $0.70 \pm 0.03$ \\
\hline $\mathrm{K}$ & 0.67 & 0.88 & $0.79 \pm 0.09$ & 0.67 & 1.02 & $0.88 \pm 0.13$ & 0.77 & 0.98 & $0.88 \pm 0.09$ \\
\hline
\end{tabular}

\# Min= Minimum, Max $=$ Maximum, S.D $=$ Standard Deviation 

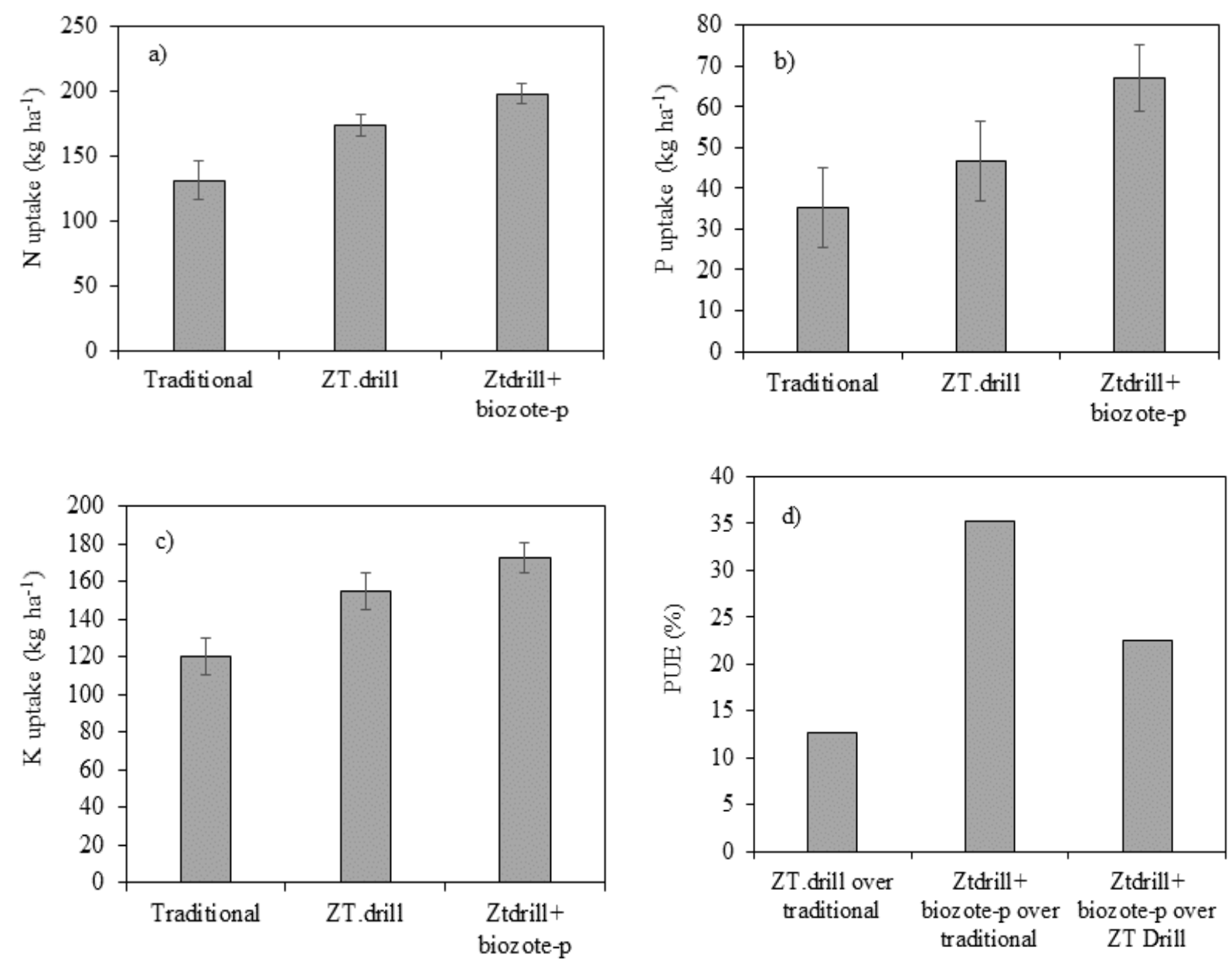

\section{Wheat planting after rice harvest with and without Biozote-P}

Figure 1. In rice-wheat cropping system at Usta Muhammad district Jafarabad, planting of wheat after rice harvest by traditional method and by zero tillage drill with and without application of Biozote-P affected $\mathrm{N}$ uptake (a), $\mathrm{P}$ uptake (b), K uptake (c) and phosphorus use efficiency (PUE) (d). Error bar represent standard error of means

\section{References}

Afzal, A., \& Bano, A. (2008). Rhizobium and phosphate solubilizing bacteria improve the yield and phosphorus uptake in wheat (Triticum aestivum). Int J Agric Biol, 10(1), 85-88.

Bhushan, L., Ladha, J.K., Gupta, R.K., Singh, S. TirolPadre, A., Saharawat, Y.S., Gathala, M., \& H. Pathak. (2007). Saving of water and labour in ricewheat system with no-tillage and direct seeding technologies. Agron. J. 99:1288-1296.

Black, C.A. (1993). Soil fertility evaluation and control. Lewis publishers, Boca Raton, Florida, USA.

Bouyoucos, G.J. (1962). Hydrometer method improved for making particle-size analysis of soils. Agron. J., 53:464-465.

Bremner, J.M. (1965). Total nitrogen. In: Methods of soil analysis. Part 2, $1^{\text {st }}$ edition. C.A. Black (Ed.)
Agronomy Society of America, Madison, Wisconsin, p.1149-1178.

Chauhan, D. S., Sharma, R. K., Tripathi, S. C., Kharub, A. S., \& Chhokar, R. S. (2000). Wheat cultivation after rice-a paradigm shift in tillage technology. Indian Farming, 50(6), 21-22.

Chauhan, H., Bagyaraj, D. J., Selvakumar, G., \& Sundaram, S. P. (2015). Novel plant growth promoting rhizobacteria-Prospects and potential. Applied Soil Ecology, 95, 38-53.

Cottenie, A. (1980). Soil and Plant testing as a basis of fertilizer recommendations. FAO soil Bulletin 38/2. Differences de techniques. Fruits, 32:151-166.

Dal Cortivo, C., Ferrari, M., Visioli, G., Lauro, M., Fornasier, F., Barion, G., Panozzo, A., \& Vamerali ,T. (2020). Effects of Seed-Applied Biofertilizers on Rhizosphere Biodiversity and Growth of 
Common Wheat (Triticum aestivum L.) in the Field. Front. Plant Sci. 11:72.

Decker, J.E., Epplin, F.M., Marley, D.L. \& Peeper, T.F. (2009). Economics of five wheat production systems with no till and conventional tillage. Agron. J. 101(2): 364-372.

Erenstein, O. (2009). Zero Tillage in the Rice-Wheat Systems of the Indo-Gangetic Plains. IFPRI Discussion Paper 00916.

Erenstein, O., \& Laxmi, V. (2008). Zero tillage impacts in India's rice-wheat system: A review. Soil Tillage Res. 100:1-14

Erenstein, O.U., Farooq, R.K., Malik, M., \& Sharif, M. (2008). On-farm impacts of zero tillage wheat in South Asia's rice-wheat systems. Field Crops Res. 105:240-252

Eskandari, H., \& Attar, S. (2015). Energy comparison of two rice cultivation systems. Renewable and Sustainable Energy Reviews, 42, 666-671.

Gangwar, K. S., Chaudhary, V. P., Gangwar, B., \& Pandey, D. K. (2009). Effect of crop establishment and tillage practices in rice (Oryza sativa)-based cropping systems. Indian journal of agricultural science, 79(5), 334-339.

Ghaffari, H., Gholizadeh, A., Biabani, A., Fallah, A., \& Mohammadian, M. (2018). Plant Growth Promoting Rhizobacteria (PGPR) Application with Different Nitrogen Fertilizer Levels in Rice (Oryza sativa L.). Pertanika Journal of Tropical Agricultural Science, 41(2). 715-728.

Gill, M. A., ur Rehman, H. M., \& Choudhary, A. (2013). 22. Enhancing Wheat Production and Productivity through Resource Conservation in Pakistan. Improving Wheat Productivity in Asia, 180-188.

Gopalakrishnan, S., Mahender Kumar, R., Humayun, P., Srinivas, V., Ratna Kumari, B., Vijayabharathi, R., \& Rupela, O. (2014). Assessment of different methods of rice (Oryza sativa. L) cultivation affecting growth parameters, soil chemical, biological, and microbiological properties, water saving, and grain yield in rice-rice system. Paddy and water environment, 12(1), 79-87.

Hussain, A., Ali, S., \& Arshad, M (1981). Isolation and identification of effective root nodule bacteria for important grain legumes of Pakistan. In: Agriculture Research Conference, Islamabad (Pakistan), 23-26 Feb, 1980. Pakistan Agricultural Research Council (PARC), Islamabad.

Jat, R. K., Sapkota, T. B., Singh, R. G., Jat, M. L., Kumar, M., \& Gupta, R. K. (2014). Seven years of conservation agriculture in a rice-wheat rotation of Eastern Gangetic Plains of South Asia: yield trends and economic profitability. Field Crops Research, 164, 199-210.

Khan, M. N., Shah, H., Qureshi, A. H., \& Abbasi, S. S. (2017). Biozote performance on wheat in on-farm trials: farmers' perceptions. Science, 36(3), 147151.

Knudsen, D., Peterson, G. A., \& Pratt, P. F. (1982). Lithium, sodium, and potassium. p. 225-246. AL Page et al.(ed.) Methods of soil analysis. Part 2. Chemical and microbiological properties. Agron. Monogr. 9. ASA and SSSA, Madison, WI. Lithium, sodium, and potassium. p. 225-246. In AL Page et al.(ed.) Methods of soil analysis. Part 2. Chemical and microbiological properties. 2nd ed. Agron. Monogr. 9. ASA and SSSA, Madison, WI.

Li, C.F., Zhang, Z.S.L., Guo, J., Cai, M.L., \& Cao, C.G. (2013). Emissions of $\mathrm{CH}_{4}$ and $\mathrm{CO}_{2}$ from double rice cropping systems under varying tillage and seeding methods. Atmos. Environ. 80: 438-444..

McLean, E. O. (1983). Soil pH and lime requirement. Methods of soil analysis: Part 2 Chemical and microbiological properties, 9, 199-224.

Meena, V. S., Maurya, B. R., \& Verma, J. P. (2014). Does a rhizospheric microorganism enhance $\mathrm{K}+$ availability in agricultural soils?. Microbiological research, 169(5-6), 337-347.

Mostara, M. R., Bhattacharya, P. B., \& Srivastava, B. (1995). Sources of nitrogen and the importance of biofertilizers P. 6. Biofertilizer technology, marketing and usage. Fertilizer development and consultation organization, 204-204.

Shahane, A. A., Shivay, Y. S., Prasanna, R., \& Kumar, D. (2020). Nutrient removal by rice-wheat cropping system as influenced by crop establishment techniques and fertilization options in conjunction with microbial inoculation. Scientific Reports, 10(1), 1-20.

Singh, V. K., Dwivedi, B. S., Singh, S. K., Mishra, R. P., Shukla, A. K., Rathore, S. S., \& Jat, M. L. (2018). Effect of tillage and crop establishment, residue management and $\mathrm{K}$ fertilization on yield, $\mathrm{K}$ use efficiency and apparent $\mathrm{K}$ balance under rice-maize system in north-western India. Field Crops Research, 224(2-3):1-12.

Stamenković, S., Beškoski, V., Karabegović, I., Lazić, M., \& Nikolić, N. (2018). Microbial fertilizers: A comprehensive review of current findings and future perspectives. Spanish Journal of Agricultural Research, 16(1). e09R01.

Subhashini, D. V. (2015). Growth promotion and increased potassium uptake of tobacco by potassium-mobilizing bacterium Frateuria aurantia grown at different potassium levels in vertisols. Communications in Soil Science and Plant Analysis, 46(2), 210-220.

Soltanpour, P. N., \& Schwab, A. P. (1977). A new soil test for simultaneous extraction of macro-and micro-nutrients in alkaline soils. Communications in Soil Science and Plant Analysis, 8(3), 195-207. 
Vejan, P., Abdullah, R., Khadiran, T., Ismail, S., \& Nasrulhaq Boyce, A. (2016). Role of plant growth promoting rhizobacteria in agricultural sustainability - a review. Molecules, 21(5), 573.

Venkatashwarlu, B. (2008). Role of bio-fertilizers in organic farming: Organic farming in rain fed agriculture: Central institute for dry land agriculture. Hyderabad. Pakistan. pp, 85-95.

Vessey, J. K. (2003). Plant growth promoting rhizobacteria as biofertilizers. Plant and soil, 255(2), 571-586.

Walkley, A. (1947). A critical examination of a rapid method for determining organic carbon in soilseffect of variations in digestion conditions and of inorganic soil constituents. Soil science, 63(4), 251-264.

Wolf, B. (1982). A comprehensive system of leaf analyses and its use for diagnosing crop nutrient status. Communications in Soil Science and Plant Analysis, 13(12), 1035-1059.

Zeffa, D. M., Perini, L. J., Silva, M. B., de Sousa, N. V., Scapim, C. A., Oliveira, A. L. M. D., ... \& Azeredo Goncalves, L. S. (2019). Azospirillum brasilense promotes increases in growth and nitrogen use efficiency of maize genotypes. Plos one, 14(4), e0215332.

Publisher's note: JOARPS remains neutral with regard to jurisdictional claims in published maps and institutional affiliations.

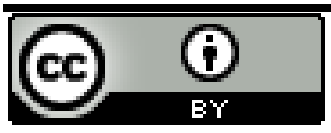

This is an open access article distributed under the terms of the Creative Commons Attribution License (CC BY 4.0), which permits unrestricted use, distribution, and reproduction in any medium, provided the original author and source are credited. To view a copy of this license, visit http://creativecommons.org/licenses/by/4.0/. 